\title{
PENGEMBANGAN INVOVASI PENDIDIKAN KOMUNIKASI MULTIKULTURAL MELALUI TAYANGAN RAGAM INDONESIA SEBAGAI STATEGI PENGUATAN IDENTITAS NASIONAL
}

\author{
Oleh: \\ Eko Digdoyo \\ Universitas Muhammadiyah Prof. DR. HAMKA \\ e-mail: ekodigdoyo77@yahoo.co.id
}

\begin{abstract}
The content of television as a public media broadcasts generally present news or social reality eventsyet it seems to be appropriate that the content must be received wisely andcritically. Receiving information without discretion will create a wrong and misleading image of the world, including an overview of multicultural education. Currently, mass media has a significant potential to instill prejudice between religions, cultures, and so on. The media in this case also has social responsibility to the public about the issues of freedom and protection of multicultural educationunderstanding. Therefore to support the theoretical approachof this study, theory about value of multicultural education whichisreinforcedby theory of social media responsibility was taken into account. The results showed thatRagam Indonesia as one of the television programs in Indonesia (in Trans 7) has been presenting shows that could be used as a good start to develop innovations in multicultural communication education, given the impressions of the content in Ragam Indonesia including the aspects of life; economics, religion, tradition, as well as local identities that can be wrapped into national identities as learning material for students, college students, and society. This kind of publication is considered to be very urgent in order to build national identity.
\end{abstract}

Key words: Inovation, Multicultural Education, Media, and National Identity

PENDAHULUAN

\section{a. Latar Belakang Masalah}

Memasuki era globalisasi, fungsi teknologi komunikasi sebagai sarana penyiaran dapat diarahkan dan difungsikan untuk mendorong dilaksanakannya nilai-nilai positif dalam masyarakat. Media khususnya televisi saat ini dianggap paling strategis untuk digunakan sebagai sarana pengembangan media pendidikan, sehingga dapat menimbulkan perubahan dengan menerapkannya dalam program pembangunan skala besar. Tugas media di sini adalah memperluas pendidikan publik dan meningkatkan inovasi baik bidang pertanian, kesehatan, keluarga berencana, serta berbagai masalah sosial dan ekonomi lainnya, maka diperlukan perhatian serius dalam 
rangka proses penguatan integrasi bangsa. Jadi, melalui wawasan tersebut pendidikan komunikasi multikultural sangat penting dalam rangka membentuk karakter bangsa Indonesia agar lebih tahu dan memahami akan karakter bangsa. Media dalam hal ini memiliki tanggungjawab sosial kepada masyarakat tentang permasalahan kebebasan dan perlindungan pemahaman terhadap pendidikan multikultural (Mering Ngo, 2002:16).

Alasan mendasar adalah saat ini media televisi menjadi salah satu kekuatan utama dalam mempengaruhi pandanganpandangan individu dan masyarakat terhadap berbagai masalah sosialbudaya. Melalui kajian ini diharapkan mampu mengembangkan inovasi pendidikan komunikasi multikultural melalui tayangan Ragam Indonesia sebagai strategi penguatan identitas nasional serta sebagai sarana sosialisasi khasanah budaya nusantara yang memiliki tingkat keanekaragaman yang sangat kompleks yang meliputi; kepercayaan (agama), suku-ras, bahasa, kesenian, sistem kemasyarakatan, sistem ekonomi, serta identitas lokal lainnya yang harus dipublikasikan.

Wacana globalisasi memang
telah hadir di tengah-tengah
kehidupan, namun dampak
globalisasi rupanya secara tidak

langsung telah melunturkan bahkan menghancurkan identitas kebudayaan (Kompas, 19 April 2014). Oleh karena itu, kekayaan budaya yang majemuk perlu penguatan nilai, baik secara ideologis maupun implementasi.

Kasus industrialisasi, konglomerasi, liberalisasi, dan kapitalisasi dalam kenyataannya telah menumbuhkan bibit-bibit masalah di masyarakat, seperti ketimpangan antara yang kaya dan yang miskin, masalah pemilik modal dan pekerja, kemiskinan, perebutan sumber daya alam, problematika terjadinya ketimpangan pendidikan, dan sebagainya. Ditambah lagi kondisi masyarakat Indonesia yang plural baik dari suku, agama, ras dan geografis memberikan kontribusi terhadap masalah-masalah sosial seperti ketimpangan sosial, konflik antar agama, golongan, suku dan sebagainya, maka jika kasus terus dibiarkan, tidak menutup kemungkinan menciptakan disharmonis bangsa.

Oleh karena itu, media saat ini dipandang perlu dijadikan pertimbangan kajian penelitian. Alasan mendasar adalah bahwa saat ini media merupakan bagian terpenting dalam memublikasikan keragaman budaya nusantara di masyarakat, bahkan media umumnya dapat menggerakkan tatanan kehidupan masyarakat. Saat ini media massa memiliki peluang yang 
sangat besar untuk menanamkan prasangka antaragama, antarbudaya, dan sebagainya (Achmad, 2001:34).

Penelitian ini memiliki ruang lingkup yang cukup penting khususnya mengenai peran media. Media dalam hal ini dianggap sebagai agen sosial khususnya dalam memberitakan atau menginformasikan nilai-nilai kebebasan dan perlindungan beragama di masyarakat, linguistik, seni, sistem kemasyarakatan serta kontek kehidupan sosial lainnya.

TRANS7 sebagai salah satu stasiun televisi di Indonesia memiliki materi tayangan yang sangat informatif, positif, dan educatif, yaitu tayangan Ragam Indonesia. Tayangan Ragam Indonesia ini disuguhkan setiap hari Senin sampai dengan Jum'at semula pukul 06.0006.30, namun saat ini ditayangkan mulai pukul 05.45-06.15 WIB. Berdasarkan pengamatan peneliti, materi tayangan berisi dinamika ragam budaya nusantara. Materi tayangan tersebut cukup menarik dan bermakna informatif dan edukatif bagi masyarakat, sehingga perlu dilakukan pengamatan, analisis kritis, sehingga dapat berkontribusi dalam upaya menguatkan nilai pendidikan khususnya pendidikan komunikasi multikultural. Oleh karena itu, media elektronik khususnya televisi menjadi media yang dipilih, karena selama ini media tersebut memiliki ciri khas masing- masing dalam memberitakan dan membangun opini di masyarakat.

Jadi, tema ini dipandang sangat penting dalam rangka memberikan porsi pendidikan komunikasi multikultural. Pendidikan komunikasi multikultural sebagai model baru dalam sistem pendidikan di Indonesia, terutama agar masyarakat khususnya peserta didik memiliki kepekaan dalam menghadapi gejala-gejala dan masalah-masalah sosial yang berakar pada perbedaan; suku, ras, agama, dan tata nilai kehidupan yang terjadi pada masyarakatnya.

Melalui kajian inilah diharapkan dapat ditranformasikan dan diimplementasikan

baik pada substansi maupun model materi pembelajaran yang mengakui dan menghormati keanekaragaman budaya.

\section{b. Masalah Pokok}

Merujuk latarbelakang di atas, terdapat beberapa masalah yang perlu dijawab dalam kajian\ ini adalah bagaimana tayangan Ragam Indonesia dapat dijadikan pengembangan inovasi pendidikan komunikasi multikultural sebagai strategi penguatan karakter identitas nasional? Serta bagaimana tanggungjawab sosial media khususnya televisi dalam memperkuat pendidikan komunikasi multikultural melalui tayangan Ragam Indonesia? 


\section{c. Pendekatan Teori dan Kajian Literatur}

Pendidikan komunikasi

multikultural merupakan sebuah konsep yang menawarkan model pendidikan yang mengusung ideologi untuk memahami, menghormati, dan menghargai harkat dan martabat manusia di manapun dia berada dan dari manapun datangnya (secara ekonomi, sosial, budaya, etnis, bahasa, keyakinan, atau agama, dan negara). Pendidikan multikultural secara inhern merupakan dambaan semua orang, lantaran keniscayaannya konsep "memanusiakan manusia". Pasti manusia yang menyadari kemanusiaanya dia akan sangat membutuhkan pendidikan model pendidikan multikultural tersebut.

H.A.R Tilaar memberikan pengertian pendidikan multikultural merupakan suatu wacana lintas batas yang mengupas permasalahan mengenai keadilan sosial, musyawarah, dan hak asasi manusia, isu-isu politik, moral, pendidikan, agama, dan ekonomi (Tilaar, 2002:24). Jadi, pendidikan multikultural adalah proses pengembangan seluruh potensi manusia yang menghargai pluralitas dan heterogenitas sebagai konsekuensi keragaman budaya etnis, suku, dan aliran (agama).

Seiring pendapat Tilaar, Ali Maksum dan Dawam menjelaskan bahwa pendidikan multikultural merupakan sebuah gerakan pembaharuan yang mengubah semua komponen pendidikan termasuk mengubah nilai dasar pendidikan, aturan prosedur, kurikulum, materi pengajaran, struktur organisasi dan kebijakan pemerintah yang merefleksikan pluralisme budaya sebagai realitas masyarakat Indonesia (Maksum, 2004, dalam Mahfud, 2008:22-24).

Merujuk pendapat di atas pengertian pendidikan multikultural adalah sebuah proses pengembangan yang tidak mengenal sekat-sekat dalam interaksi manusia. Sebagai wahana pengembangan potensi, pendidikan multikultural adalah pendidikan yang menghargai heterogenitas dan pluralitas, dalam arti lain pendidikan yang menjunjung tinggi nilai kebudayaan, etnis, suku, agama, ekonomi, seni, dan kondisi geografis.

Kajian ini menurut hemat peneliti lebih tepat jika menggunakan pendekatan teori tanggungjawab sosial media. Teori tanggung jawab sosial media menyatakan bahwa media harus meningkatkan standar secara mandiri, menyediakan materi dan pedoman netral bagi warga negara yang membutuhkan materi tanyangan terkait isu multikultural melalui media (Wridgh, 1985). Jadi, para pemilik media yang sangat sukses biasanya mengatur surat kabar, layanan via kabel, stasiun radio, studio film, dan majalah (jika 
dalam media elektronik termasuk isi atau materi tayangan).

Teori tanggung jawab sosial dikembangkan setelah Roosevelt, ketika para penerbit berpengaruh tidak populer di kalangan publik. Publik selalu curiga terhadap pers, bahkan ketika para pemimpin industri diganti dengan yang baru. Pers telah merumuskan "kode etik" selama berdekade (Masyarakat Editor Surat Kabar Amerika (ASNE) menerapkan "aturan jurnalisme" (The Canons of Journalism) di tahun 1923) dan televisi menjadi media paling populer pada saat itu.

Melalui paradigma baru, para jurnalis tersebut menawarkan perspektif baru. Sebab melalui media eletronik berorientasi pada khalayak. Untuk itu teori tanggung jawab sosial tidak bertentangan dengan hukum yang berlaku. Teori tanggung jawab sosial memiliki pandangan "liberal" terhadap diskursus publik yang sehat. Jadi, melalui teori tersebut media dianggap sebagai mitra dalam mencari kebenaran (Nasution, 1983). Artinya semua pendapat harus mendapat kesempatan yang sama untuk didengar atau dilihat, maka harus ada pasar bebas pemikiranpemikiran dan informasi (Sardar, 1988 dalam Jacobus, 2006).

Teori Tanggungjawab Sosial (media) mempunyai asumsi utama: bahwa kebebasan, mengandung makna tanggung jawab terhormat. Oleh karena itu, harus dapat dipertanggungjawabkan kepada masyarakat dalam menjalankan fungsi-fungsi penting komunikasi massa dalam masyarakat modern. Untuk itu, perlu dibangun melalui wacana bahwa tanggungjawab sosial media melalui aspek kehidupan.

Dalam kajian ini TRANS7 sebagai salah satu media elektronik memiliki tanggungjawab sosial dalam membangun wacana publik melalui tayangan Ragam Indonesia. Ragam Indonesia itulah sebagai salah satu tayangan yang mendidik dan menyosialisasikan ragam sosialbudaya di masyarakat sebagai kenyataan yang menjadi identitas nasional bangsa.

Keanekaragaman budaya, agama, serta adat yang ada telah dibangun oleh ideologi bangsa yaitu Pancasila. Di dalam ideologi itulah masyarakat Indonesia ditawarkan nilai-nilai kebebasan di dalam berbudaya. Sebagaimana dikemukakan oleh Rufini (La liberté religiosa, 1901, terjemahan Inggris 1912) berarti: menciptakan suatu kondisi dalam masyarakat di mana seorang manusia dapat menuntut tujuan-tujuan spiritual yang tertinggi dengan tidak dihalangi orang lain (Dahrendof, 1986), sehingga kepribadian individu dalam masyarakat tersebut dapat dianggap mampu untuk memilih dan menentukan nasibnya sendiri, maka harus bebas.

Sebagai bangsa yang mengembangkan falsafah kehidupan yang menjunjung tinggi keteraturan 
sosial berdasar atas falsafah Pancasila, UUD 1945 dan peraturan perundang-undangan lainnya, maka tentu saja kita akan menjadikan kebebasan berbasis tanggungjawab sosial sebagai inti dari kebebasan yang kita kembangkan. Untuk itu kita juga tidak cocok menggunakan model kaum otoritarian yang beranggapan bahwa tidak ada kebebasan, semuanya diatur dan dikendalikan (Departemen Agama Republik Indonesia, 2003).

Jadi, kebebasan tidak berdiri sendiri, tetapi terkait dengan kebebasan lain yaitu kebebasan berpikir, dan berkesadaran atau berhati nurani. Kebebasan bersifat mutlak, dan berada di dalam forum internum yang merupakan wujud dari inner freedom (freedom to be) dan itu termasuk hak non derogable (tak bisa ditangguhkan pemenuhannya oleh negara dalam keadaan apapun). Oleh karena itu, diperlukan pedoman atau aturan yang mengatur agar kategori hak bertindak (freedom to act) tersebut tidak menjadi ancaman bagi keteraturan sosial.

Jika merujuk argumentasi di atas, negara Indonesia merupakan negara yang plural (majemuk), kemajemukan Indonesia ini ditandai dengan adanya multikultural yang dianut oleh penduduk, suku bangsa, golongan, dan ras. Letak geografis Indonesia yang berada di tengahtengah dua benua, menjadikan negara ini terdiri dari berbagai ras, suku bangsa, dan agama. Untuk itu, tidak diragukan lagi, perjalanan panjang sejarah bangsa Indonesia itu mengakibatkan adanya kemajemukan yang dianut oleh bangsa Indonesia dari masa ke masa.

Misalnya aspek agama dapat menjadi pendorong dan pendukung arah pembangunan Indonesia. Pada sisi lain, isu tentang agama dapat menjadi pemicu konflik antar umat beragama (Robert, 1993:36). Oleh sebab itu, hubungan baik antar umat beragama yang terwujud dalam tiga kerukunan hidup beragama Indonesia diharapkan selalu terwujud dalam perjalanan hidup bangsa. Setiap agama mengajarkan kebenaran dan kebaikan (Abdullah, 1983:40). Untuk itu diperlukan media sebagai model pembelajaran dalam penguatan identitas nasional.

\section{d. Metode dan Jenis Penelitian} Penelitian ini merupakan jenis penelitian yang menggunakan pendekatan kualitatif (Qualitative Research). Melalui pendekatan ini diharapkan dapat menganalisis kehidupan masyarakat tertentu, sejarah, tingkah laku, fungsionalisasi organisasi, gerakan sosial (Basrowi, Suwandi, 2008, dan Hamdi, 2004:75). Sementara itu jenis penelitian adalah deskriptif yang bertujuan untuk menggambarkan, meringkas berbagai kondisi, situasi, atau berbagai fenomena realitas sosial yang ada di masyarakat yang 
menjadi obyek penelitian, dan berupaya menarik realitas itu ke permukaan sebagai suatu ciri, karakter, sifat, model, tanda atau gambaran tentang kondisi, situasi, ataupun fenomena yang terkait media dan budaya. Selanjutnya mengidentifikasi serta melakukan pengamatan dalam tayangan media khususnya dalam Ragam Indonesia di TRANS7, sebagai sarana pembelajaran untuk memperkuat nilai-nilai multikultural. Didasari pada fokus penelitian mengenai pendidikan komunikasi multiultural, maka di samping penggunaan buku atau sumber terkait, data diperoleh melalui pengamatan media khususnya melalui isi tayangan televisi khususnya stasiun televisi TRANS7. Untuk dapat menjawab permasalahan penelitian secara efisien dan efektif, maka penelitian ini dirancang menggunakan penelitian pengamatan dan naturalistik kualitatif (Creswell, 2010), berikut alur pemikiran proses penelitian.

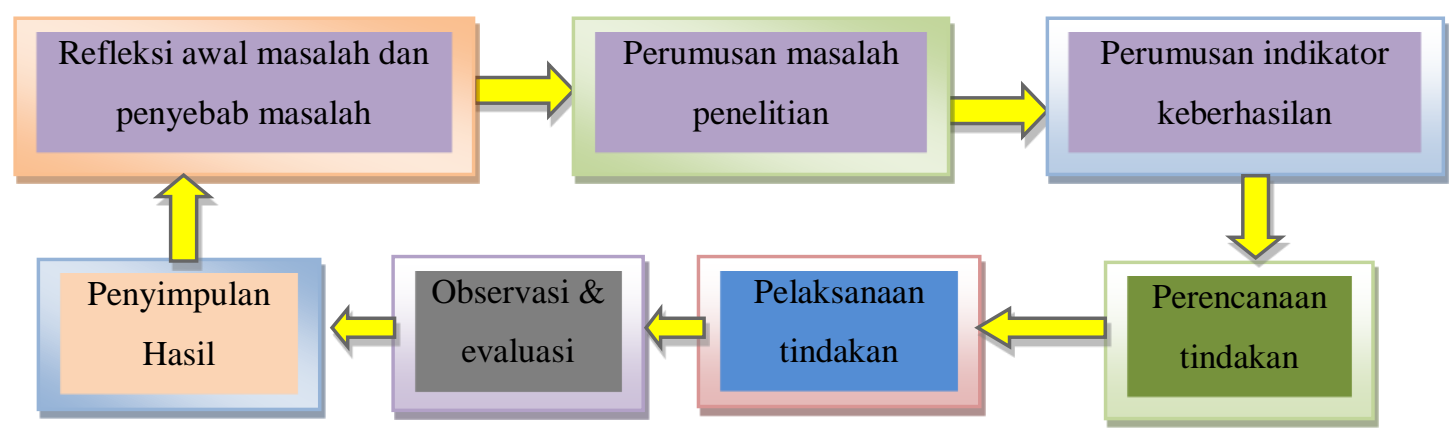

Gambar 1. Implementasi Penelitian

\section{Hasil Penelitian dan Pembahasan}

a. Sekilas Tentang TRANS7

TRANS7 (sebelumnya bernama TV7) adalah sebuah stasiun televisi swasta nasional di Indonesia dan melakukan siaran perdananya di Jakarta pada 23 November 2001 dan pada saat itulah mayoritas sahamnya dimiliki oleh Kompas Gramedia. Pada tanggal 4 Agustus 2006. Trans Corp mengakuisisi mayoritas saham TV7. Sejak itulah TV7 dan TransTV resmi bergabung, namun ternyata TV7 masih dimiliki oleh Kompas Gramedia, sampai TV7 akhirnya melakukan re-launch (peluncuran ulang) pada 15 Desember 2006 dan menggunakan nama baru, yaitu TRANS7.

TRANS7 yang semula bernama TV7 berdiri dengan izin dari Departemen Perdagangan dan Perindustrian Jakarta Pusat dengan Nomor $\quad$ 809/BH.09.05/III/2000 (http://www.trans7.co.id). Pada 22 Maret 2000, keberadaan TV7 telah diumumkan dalam Berita Negara Nomor 8687 sebagai PT. Duta Visual Nusantara Tivi Tujuh. Melalui kerjasama strategis antara Para 
Group dan KKG, TV7 melakukan relaunching pada 15 Desember 2006 sebagai TRANS7 dan menetapkan tanggal tersebut sebagai hari lahirnya TRANS7. Di bawah naungan PT Trans Corpora yang merupakan bagian dari manajemen Para Group, TRANS7 diharapkan dapat menjadi televisi yang maju, dengan programprogram in-house productions yang bersifat informatif, kreatif, dan inovatif.

Hingga saat ini, TRANS7 dengan komitmen menyajikan tayangan berupa informasi dan hiburan, menghiasi layar kaca di ruang keluarga pemirsa Indonesia. Berawal dari kerjasama strategis antara Para Group dan Kelompok Kompas Gramedia (KKG) pada tanggal 4 Agustus 2006, TRANS7 lahir sebagai sebuah stasiun swasta yang menyajikan tayangan yang mengutamakan kecerdasan, ketajaman, kehangatan penuh hiburan serta kepribadian yang aktif. Guna memberikan informasi mendalam tentang perkembangan TRANS7 berikut keberadaan logo sebelum dan sesudah perubahan nama dari perusahaan Trans Group.
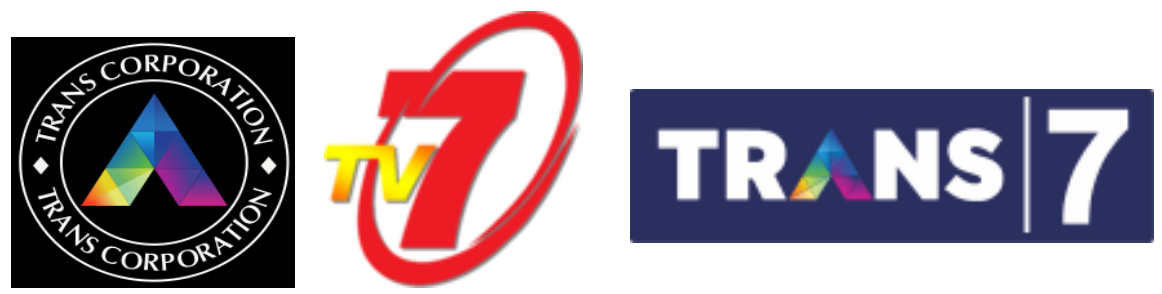

Gambar 2. Logo TRANS7 sebelum dan sesudah perubahan

Sumber : http://www.trans7.co.id

Sebagai salah satu Group Trans Media dan sebagai media terdepan di Indonesia, TRANS7 konsisten menghadirkan karya penuh inovasi dan menjadi trendsetter untuk Indonesia yang lebih baik, maka memiliki identitas baru. Untuk itu tepatnya pada hari Minggu, 15 Desember 2013, TRANS7 meluncurkan logo baru bersamaan dengan ulang tahun Trans Media yang ke-12. Logo dengan simbol "Diamond A" di tengah kata
TRANS7 merefleksikan kekuatan dan semangat baru yang memberikan inspirasi bagi semua orang di dalamnya untuk menghasilkan karya yang gemilang, diversifikasi konten atau keunikan tersendiri serta kepemimpinan yang kuat.

Semua rangkaian warna yang mengandung makna cerita di dalamnya, menyatu dengan serasi dan membentuk simbol yang utuh, kuat dan bercahaya di dalam berlian berbentuk A ini, sehingga bisa 
dipahami makna dari logo baru TRANS7 ini menjadi tanda yang menyuarakan sebuah semangat dan perjuangan untuk mencapai keunggulan yang tiada banding mulai dari sekarang hingga masa mendatang.

\section{Visi, Misi, dan Slogan}

Visi: Dalam jangka panjang, TRANS7 menjadi stasiun televisi terbaik di Indonesia dan di ASEAN dan TRANS7 juga berkomitmen selalu memberikan yang terbaik bagi stakeholders dengan menayangkan program berkualitas dan mempertahankan moral serta budaya kerja yang dapat diterima stakeholders

Misi: TRANS7 menjadi wadah ide dan aspirasi guna mengedukasi dan meningkatkan kualitas hidup masyarakat, dan TRANS7 berkomitmen untuk menjaga keutuhan bangsa serta nilai-nilai demokrasi dengan memperbaharui kualitas tayangan bermoral yang dapat diterima masyarakat dan mitra kerja.

Slogan TRANS7: Makin Beragam, Makin Seru! (2001-2003), Memberi Inspirasi (2003-2005), Semakin Beragam, Semakin Menarik (20052006), dan Milik Kita Bersama (2006-sekarang)

Jadi, semenjak era reformasi, dunia pertelevisian di Indonesia mengalami perkembangan yang cukup signifikan. Perkembangan ini ditandai dengan banyaknya stasiun televisi swasta yang mengudara di Indonesia. Saat ini, ada sekitar 11 stasiun televisi di Indonesia, satu televisi pemerintah, yaitu TVRI dan 10 televisi swasta, salah satunya adalah TRANS7. Seiring dengan persaingan media televisi, TRANS7 merupakan salah satu stasiun televisi swasta nasional di Indonesia yang memiliki komitmen untuk menyajikan tayangan berupa informasi, pendidikan, dan hiburan yang menghiasi layar kaca keluarga pemirsa Indonesia. Misalnya, Redaksi yang hadir setiap pagi, siang, sore, dan malam yang dikemas secara apik dan dinamis, update dan informatif.

Program yang tak kalah menarik dan mengedukasi lainnya menurut pandangan peneliti adalah KHAZANAH, RAGAM INDONESIA, RAGAM DUNIA, dan RAGAM MANFAAT. Namun demikian kajian ini fokus pada tayangan RAGAM IINDONESIA. Sebab tayangan RAGAM INDONESIA bermakna edukatif, menampilkan kekayaan alam seni, budaya, religi, niaga, dan wisata kuliner khas yang ada di seluruh nusantara.

\section{b. Materi Tayangan RAGAM INDONESIA}

Tayangan

RAGAM

INDONESIA merupakan salah satu materi tanyangan media televisi khususnya TRANS7. Materi tayangan RAGAM INDONESIA ini 
disajikan semula setiap hari Senin sampai Jumat pukul 06.00 sampai dengan 06.30 (durasi 30 menit), namun saat ini mulai tayang pada pukul 05.40-06.15. Waktu atau durasi tersebut memang hanya sebentar, namun di balik tayangan ini memiliki makna serta pesan edukasi bagi anak bangsa terkait pembentukan karakter terhadap penguatan nilai-nilai multikultural di Indonesia sebagai modal membangun penguatan identitas nasional.

Materi tayangan ini meliputi keragaman sosial ekonomi, nilai-nilai adat-istiadat, seni, religi, bahasa, wisata yang meliputi wisata religi, niaga, alam, dan berbagai jenis wisata kuliner nusantara. Kemudian dalam identitas budaya lokal lainnya terkait ekonomi kreatif masyarakat kota dan desa. Oleh karena itu materi tayangan Ragam Indonesia sangat informatif dalam kajian ini, sehingga wawasan budaya nusantara dapat menjadi modal dan model pembelajaran terkini bagi generasi muda.

Tayangan serupa di TRANS7 diperkuat jenis tanyangan lain seperti; Bocah Petualang ditayangkan pukul 13.15 s/d 13.45,
Jejak Petualang ditayangkan pukul $15.15 \mathrm{~s} / \mathrm{d} 15.45$, dan materi tayangan Orang Pinggiran ditayangkan pukul 15.45 s/d 16.15. Oleh karena itu materi tanyangan tersebut memiliki makna simbolik, educatif, dan kepedulian sosial terhadap sesamanya. Tayangan di stasiun televisi lain misalnya TRANS7 terdapat Kisah-Kisah Kehidupan ditayangkan pukul $19.00 \mathrm{~s} / \mathrm{d} 20.00$. Kemudian di televisi publik khususnya TVRI misalnya tanyangan Negeri Indonesia dan Kuliner Indonesia pukul $11.03 \mathrm{~s} / \mathrm{d}$ 11.30, khusus tanyangan seni dan budaya ditayangkan setiap pukul 00 s/d 01.00 .

Alasan dipilihnya Stasiun TRANS7 karena stasiun ini memiliki komitmen kepada publik dalam menayangkan ragam identitas sosialbudaya Indonesia. Untuk itu melalui penelitian ini, penulis berkesimpulan sementara bahwa materi tayangan RAGAM INDONESIA dapat menjadi inspirasi dan inovasi pembelajaran baik siswa, mahasiswa, maupun masyarakat umum. Secara khusus slogan tayangan RAGAM INDONESIA ditampilkan berikut ini. 


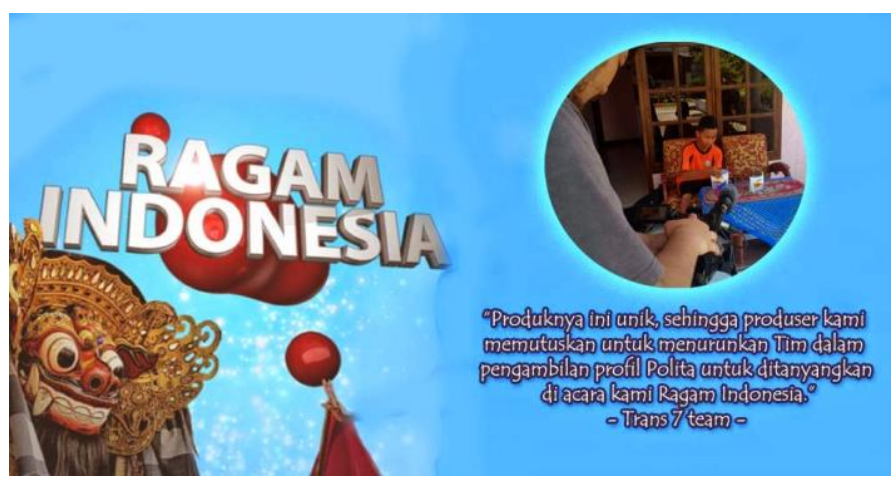

Gambar 3. Slogan Tampilan Ragam Indonesia

Sumber: http://www.trans7.co.id

Berdasarkan materi tayangan Ragam Indonesia selama ini, perlu dijadikan materi pembelajaran dinamika kebudayaan sebagai identitas nasional, maka dipaparkan dalam wujud kebudayaan berikut ini.

1. Wujud Keanekaragaman Budaya Nasional

Kebudayaan daerah tercermin dalam berbagai aspek kehidupan masyarakat di seluruh daerah di Indonesia. Setiap daerah memiliki ciri khas kebudayaan yang berbeda. Berikut ini beberapa kebudayaan Indonesia berdasarkan jenisnya:

a. Upacara Adat dan Religi

Dalam kajian antropologi, upacara adat dan sistem religi merupakan bagian kajian dari budaya, dan suatu bentuk tradisi yang bersifat turun-temurun yang dilaksanakan secara teratur dan tertib menurut adat kebiasaan masyarakat dalam bentuk suatu rangkaian aktivitas permohonan sebagai ungkapan rasa terima kasih. Selain itu, upacara adat merupakan perwujudan dari sistem kepercayaan masyarakat yang mempunyai nilainilai universal, bernilai sakral, suci, religius, dilakukan secara turuntemurun serta menjadi kekayaan kebudayaan nasional. Unsur-unsur dalam upacara adat meliputi: tempat upacara, waktu pelaksanaan, bendabenda/peralatan dan pelaku upacara yang meliputi pemimpin dan peserta upacara. Jenis-jenis upacara adat di Indonesia antara lain: Upacara kelahiran, perkawinan, kematian, penguburan, pemujaan, pengukuhan kepala suku dan sebagainya.

Beberapa upacara adat tradisional dan sistem religi yang dilaksanakan masyarakat dan menjadi identitas nasional dan kemudian menjadi materi tayang dalam Ragam Indonesia berdasarkan wilayah geografis antara lain: 


\section{Tabel 1}

Materi Tayangan Ragam Indonesia Berdasarkan Sistem Religi

\begin{tabular}{|c|c|c|}
\hline No. & $\begin{array}{l}\text { Nama } \\
\text { Wilayah }\end{array}$ & Nama Sistem Religi \\
\hline 1 & Sumatera & $\begin{array}{l}\text { Peucicap, Peusijuek dapu, dan Peutron Aneuk di } \\
\text { Aceh, Tabuik Balimau, Makan bajamba di } \\
\text { Sumatera Barat, Basuh lantai dan Mandi Safar } \\
\text { Melayu, Ratif saman dan Tepuk tepung tawar di } \\
\text { Kepulauan Riau. }\end{array}$ \\
\hline 2 & Jawa & $\begin{array}{l}\text { Seren taun di Jawa Barat, Mitoni, tedak siti, } \\
\text { ruwatan, kenduri, grebegan di Jawa Tengah, } \\
\text { Yogyakarta dan Jawa Timur, Dugderan oleh } \\
\text { masyarakat Semarang, dan Kasodo oleh } \\
\text { masyarakat Tengger. }\end{array}$ \\
\hline 3 & Kalimantan & $\begin{array}{l}\text { Gawai Dayak masyarakat Dayak dan Robo-robo } \\
\text { masyarakat Mempawah, Kalimantan Tengah } \\
\text { dikenal Tiwah di Dayak Ngaju. Kalimantan } \\
\text { Selatan melakukan upaca adat; Baayun Mulud, } \\
\text { Badudus, Bapapai masyarakat Banjar, Aruh } \\
\text { Baharin masyarakat Dayak, Mappanretasi } \\
\text { masyarakat Bugis Pagatan, dan Macceratasi } \\
\text { masyarakat Kotabaru Kalimantan Selatan. } \\
\text { Sementara untuk Kalimantan Timur melakukan } \\
\text { upacara adat dikenal dengan Erau di Kutai } \\
\text { Kartanegara. }\end{array}$ \\
\hline 4 & Sulawesi & $\begin{array}{l}\text { Mapasilaga tedong suku Toraja dan Rambu solo } \\
\text { suku Toraja. }\end{array}$ \\
\hline 5 & $\begin{array}{l}\text { Bali dan Nusa } \\
\text { Tenggara }\end{array}$ & $\begin{array}{l}\text { Subak dan Ngaben di Bali, Nelu bulanin di Bali, } \\
\text { dan Pasola sumba di Pulau Sumba. }\end{array}$ \\
\hline 6 & Maluku & $\begin{array}{l}\text { Kololi kie di Maluku Utara, Pukul sapu, Abdau } \\
\text { dan Buka sasi lompa di Maluku. }\end{array}$ \\
\hline 7 & Papua & $\begin{array}{l}\text { Barapen atau Bakar batu di Papua dan Sanepen di } \\
\text { Biak, dst. }\end{array}$ \\
\hline
\end{tabular}

b. Kesenian Daerah

Dalam tayangan Ragam Indonesia di TRANS7 jenis kesenian 
yang sering disuguhkan kepada pemirsa meliputi; seni tari, suara, dan desainner tradisonal. Sebagaimana kita ketahui jenis tari tradisional merupakan bagian dari budaya daerah yang menyusun kebudayaan nasional Indonesia. Berdasarkan tradisinya, tarian Indonesia dibagi dalam dua kelompok; tari tradisional dan tari kontemporer. Sebagai kebanggaan khasanah ragam budaya bangsa, berikut sekilas penjelasan dan contoh gambar tarian bercorak prasejarah dari suku pedalaman yang menjadi materi tayangan Ragam Indonesia dapat dilihat gambar berikut ini:

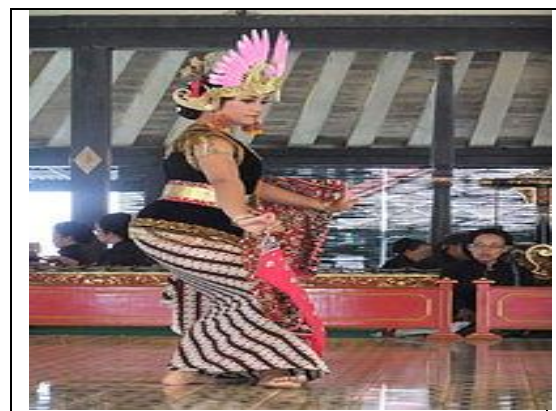

Gambar 4.1 Tari Golek Ayun-ayun, dari Keraton Yogyakarta

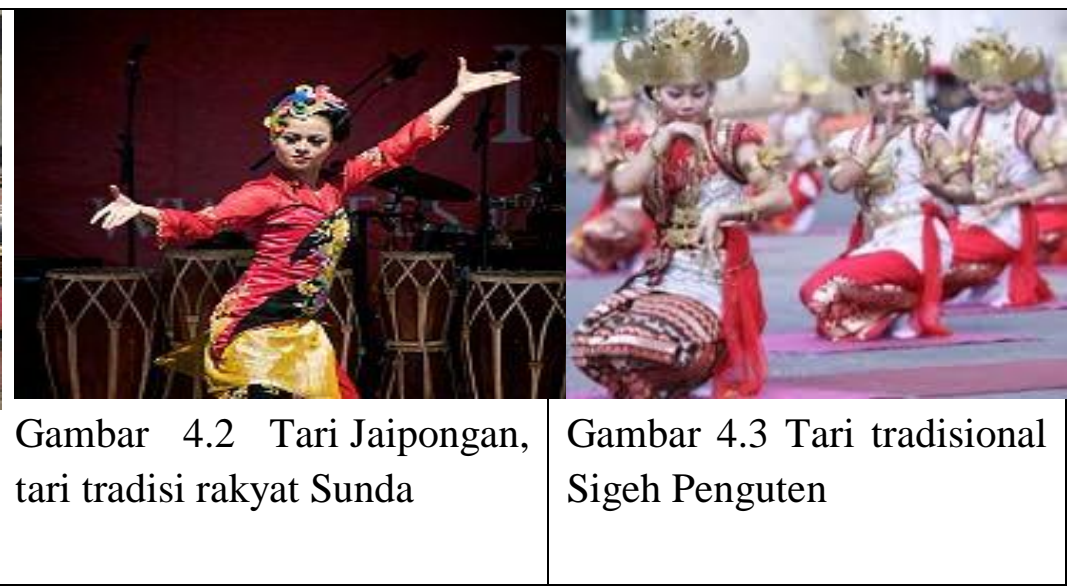

Sumber: Ragam Indonesia.com
Jadi, seni tari tradisional Indonesia mencerminkan kekayaan dan keanekaragaman bangsa Indonesia. Beberapa tradisi seni tari seperti; tarian Bali, tarian Jawa, tarian Sunda, tarian Minangkabau, tarian Palembang, tarian Melayu, tarian Aceh, dan masih banyak lagi adalah seni tari yang berkembang sejak dahulu kala, meskipun demikian tari ini tetap dikembangkan hingga kini. Penciptaan tari dengan koreografi baru, tetapi masih di dalam kerangka disiplin tradisi tari tertentu masih dimungkinkan. Sebagai hasilnya, munculah beberapa tari kreasi baru. Tari kreasi baru ini dapat merupakan penggalian kembali akar-akar budaya yang telah sirna, penafsiran baru, inspirasi atau eksplorasi seni baru atas seni tari tradisional.

Sementara itu jenis seni gambar yang sering menjadi materi tayangan dalam Ragam Indonesia di TRANS7 misalnya; Jawa terdapat seni Wayang, dan Sumatera Utara terdapat seni Tortor. Kemudian seni patung misalnya di Jawa terdapat Candi Borobudur, Prambanan, Mendut, dan patung di Jawa Timur. Di Bali terdapat jenis patung Garuda Wisnu Kencana, di Papua Asmat terdapat patung yang bersifat totemisme yang menggabungkan makna religi dengan alam. 
c. Wisata Niaga dan Kuliner

Tayangan Ragam Indonesia

TRANS7 yang tidak kalah menariknya adalah ragam kuliner nusantara. Kuliner nusantara merupakan kebanggaan khas warga Indonesia, sebab masing-masing daerah memiliki ciri khas kuliner yang unik, menarik dan penuh cita rasa. Indonesia dikenal sebagai negeri yang kaya, tidak hanya hasil alam yang melimpah, namun juga dari beragamnya suku, sehingga masing-masing suku menghasilkan macam kuliner yang menggugah selera. Mulai dari Pulau dan Kepulauan di Sumatera, Jawa, Kalimantan, Sulawesi, kepulauan Lombok, Bali, dan Maluku, serta Papua umumnya memiliki ciri khas kuliner.

\section{d. Wisata Alam di Indonesia}

Dalam program Ragam Indonesia terdapat tayangan yang memiliki khasanah keindahan alam yang luar biasa. Keindahan yang terasa nikmat untuk berlibur dan berkumpul bersama keluarga misalnya Pantai Karimun Jawa, Jawa Tengah. Keindahan alam yang dimiliki pulau Karimun Jawa ini sangat cocok bagi anak-anak, remaja, dan orang tua. Karimun Jawa memiliki suasana yang sangat mendukung untuk berwisata. Taman Nasional Karimun Jawa yang indah dengan deburan ombak yang tenang dan pasir yang putih bersih. Selain itu, fasilitas yang disediakan sangat bervariasi, sehingga para pelancong yang datang tidak kesulitan dalam memenuhi keinginannya.

Ragam Indonesia dalam jenis wisata alam berikutnya adalah Pulau Moyo, Nusa Tenggara Barat. Pulau ini menawarkan keindahan pantai dengan pasir putih ini cocok bagi para wisatawan baik asing maupun domestik. Setiap penginapan bahkan menyediakan fasilitas bagi para wisatawan yang tertarik melakukan diving untuk melihat beragam penghuni.

Keindahan alam dalam suguhan wisata alam berikutnya adalah Kampung Sampireun, Garut, Jawa Barat. Kampung yang berada di kota Garut, Jawa Barat ini menawarkan kesan tradisional dan kenyamanan dengan segala fasilitas bagi para wisatawan khususnya bagi para pasangan yang ingin mencari tempat yang romantis. Pemandangan yang indah dan lingkungan yang tenang, udara bersih dan segar itu menjadikan tempat ini sangat tepat untuk pasangan yang berbulan madu. Selain itu, bangunan penginapan yang ada terbuat dari bambu dan atap daun kelapa memberikan kesan rumah jaman dahulu yang masih sederhana.

Selanjutnya adalah Ragam Indonesia dalam bentuk wisata alam di Pulau Seribu, Jakarta. Kabupaten Pulau Seribu yang berada di daerah Jakarta ini terdiri dari ratusan pulau kecil. Maka dari itu, para wisatawan 
ditawarkan dengan pilihan pulau yang memiliki keindahan tersendiri, mulai dari pulau Anyer, pulau Bidadari, pulu Untung Jawa, pulau Pramuka dan masih banyak lagi yang disajikan pemandangan yang indah.

Keindahan wisata desa di

Ubud, Bali. Desa Ubud yang bertempat di Kabupaten Gianyar, Bali ini menjadi salah satu desa seni yang bertaraf internasional. Desa Ubud tersebut dilengkapi suguhan desa wisata dalam bentuk Subak, sehingga tampak asri dan alami.

Kemudian wisata Desa Tembi, Bantul, Yogyakarta. Wisata desa ini pernah menjadi suguhan tayangan Ragam Indonesia, sehingga akan menemukan satu tempat yang dibangun dari rumah dan lingkungan tradisional asli Jawa Yogyakarta yang disebut Omah Tembi. Omah Tembi adalah gabungan dari rumah asli penduduk setempat, yang dibangun menjadi suatu tempat peristirahatan. Keberadaannya berpadu dengan bangunan khas seperti; pendopo, joglo serta halaman yang luas. Keberadaan saung dan sawah di dekatnya mempertegas suasana kedesaannya. Di area Omah Tembi ini wisatawan bisa melakukan beberapa aktivitas lain seperti; kegiatan mengelilingi Kawasan Wisata Gabusan-Manding-Tembi, menggunakan kereta mini, menaiki andong, atau becak, sambil berbelanja dan menikmati jajanan serta makanan khas daerah setempat.
Tayangan berikutnya adalah lokasi wisata alam Kepualaun Derawan, Berau, Kalimantan Timur. Derawan mewakili romantisme Kalimantan. Selama di lokasi, wisatawan bisa menikmati keindahan alam, mulai dari hutan yang menyimpan beraneka ragam tanaman dan binatang, barisan pohon kelapa dan pasir pantai yang lembut, permukaan laut berwarna gradasi biru dan hijau, serta pemandangan bawah laut yang mengagumkan. Kepulauan Derawan merupakan satu dari sekian tujuan penyelaman utama dunia. Jika beruntung, wisatawan bisa melaju bersama rombongan penyu atau ikan hias di permukaan laut yang jernih. Di lokasi tersebut juga tersedia penginapan. Baik kelas melati atau cottage pinggir pantai yang menyenangkan.

Jadi, Indonesia memang surga wisata alam yang menawarkan berbagai keindahan dan ketenangan di dalamnya. Tak hanya untuk berlibur tapi juga untuk menambah kehangatan para wisatwaan. Tayangan ini hanyalah sebagian kecil dari materi tayangan di layar kaca TRANS7 yang telah disuguhkan oleh pemirsa. Untuk itu melalui tayangan tersebut secara tidak langsung memberikan bukti Ragam Indonesia dalam bentuk alam yang perlu dinikmati, dan perlu dipelajari eksistensinya. Berikut adalah buktibukti tayangan Ragam Indonesia dalam jenis wisata alam: 


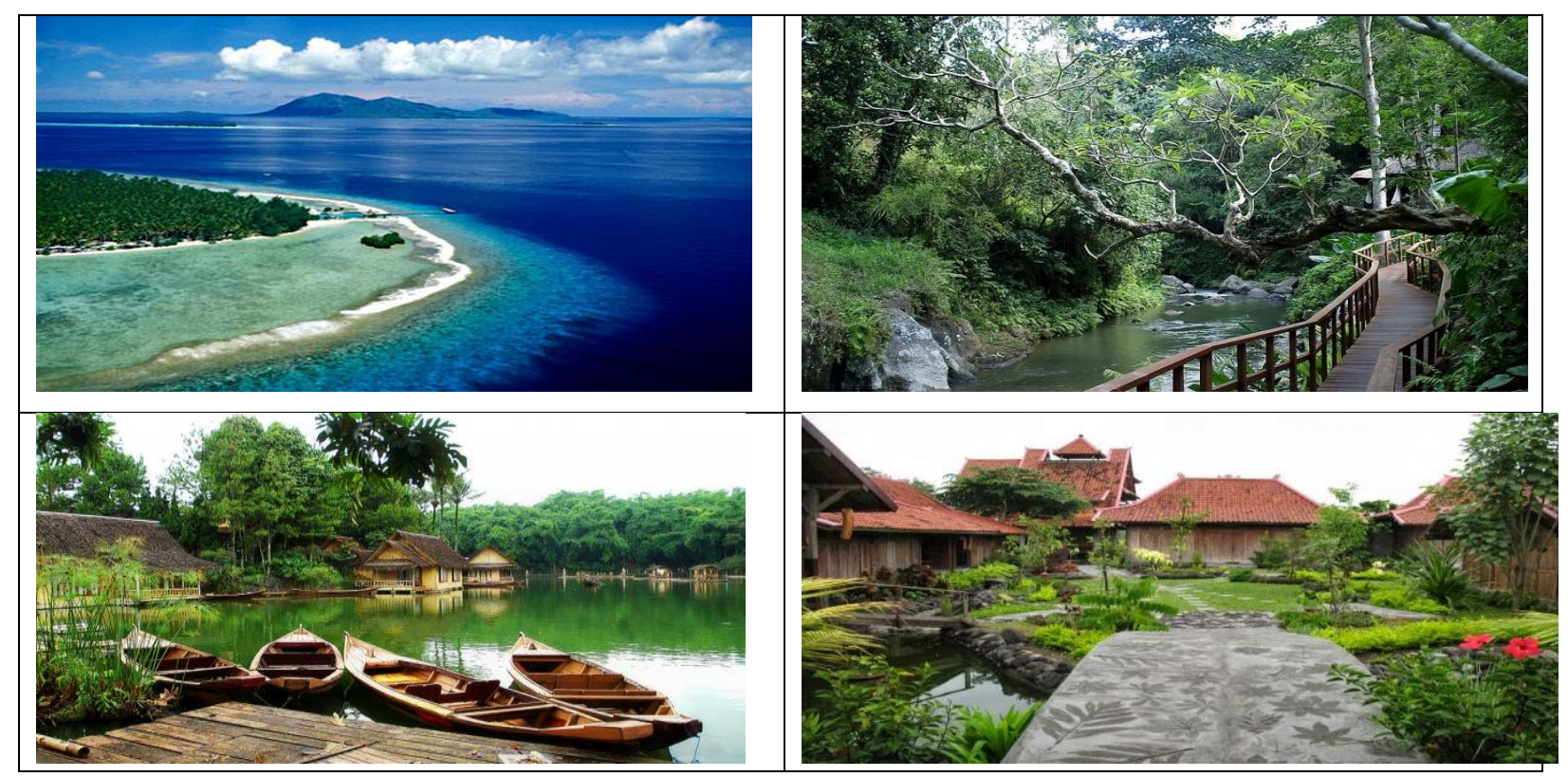

Gambar 5. Foto Wisata Alam Pilihan Ragam Indonesia

Sumber: Ragam Indonesia.com

c. Urgensi

Komunikasi Mutikultural sebagai Penguatan Identitas Nasional

Bagi penulis, pendidikan adalah upaya sadar manusia untuk melakukan perubahan serta peningkatan pengetahuan yang lebih baik dalam rangka mencapai kehidupan yang lebih baik. Dalam hal ini pendidikan dimaknai upaya pengubahan sikap, perilaku, wawasan, ketrampilan dan tindakan lainnya dari tidak mengerti menjadi lebih mengerti, dari tidak paham menjadi lebih paham, dari tidak terampil menjadi lebih terampil, dan dari tidak hebat bisa dipahami menjadi lebih hebat, dan itu semua berkat pendidikan.

Kemudian pendidikan multikultural dimaknai upaya melakukan pembelajaran dalam peningkatan demokratisasi peserta didik dalam menghadapi perbedaan budaya. Oleh karena itu, pendidikan multikultural adalah merupakan suatu wacana lintas batas, karena terkait dengan masalah-masalah keadilan sosial (social justice), demokrasi dan hak asasi manusia (Mahfud, 2008: 16, dan Yakin, 2005: 41). Tokoh pendidikan Indonesia Azyumardi Azra mendefinisikan pendidikan multikultural sebagai pendidikan untuk atau tentang 
keragaman kebudayaan dalam merespon perubahan demografi dan kultur lingkungan masyarakat tertentu atau secara keseluruhan.

$$
\text { Selanjutnya }
$$

Crandall mengemukakan bahwa pendidikan multikultural adalah pendidikan yang memperhatikan secara sungguhsungguh terhadap latar belakang peserta didik baik dari aspek keragaman suku (etnis), ras, agama (aliran kepercayaam) dan budaya (kultur) (dalam Tilaar, 2002:47). Kemudian lebih singkat Andersen dan Custer (1994) mengatakan bahwa pendidikan multikultural adalah pendidikan mengenai keragaman budaya. Musa Asy'ari juga menyatakan bahwa pendidikan multikultural adalah proses penanaman cara hidup menghormati, tulus, dan toleran terhadap keanekaragaman budaya yang hidup di tengah-tengah masyarakat plural (Tilaar, 2002:68 dan Zamroni, 2011:57). Dari uraian definisi pendidikan multikultural tersebut di atas, cukup ideal untuk digunakan sebagai referensi dalam penulisan ini.

Berdasarkan konseptual di atas, multikultural berarti beraneka ragam kebudayaan. Menurut Suparlan (2002:36) akar kata dari multikulturalisme adalah kebudayaan, yaitu kebudayaan yang dilihat dari fungsinya sebagai pedoman bagi kehidupan manusia. Dalam konteks pembangunan bangsa, istilah multikultural ini telah membentuk suatu ideologi yang disebut multikulturalisme. Konsep multikulturalisme tidaklah dapat disamakan dengan konsep keanekaragaman secara suku bangsa atau kebudayaan suku bangsa yang menjadi ciri masyarakat majemuk, karena multikulturalisme menekankan keanekaragaman kebudayaan dalam kesederajatan.

Jadi, kajian mengenai multikulturalisme mau tidak mau akan mengulas berbagai permasalahan yang mendukung ideologi ini, yaitu politik dan demokrasi, keadilan dan penegakan hukum, kesempatan kerja dan berusaha, HAM, hak budaya komunitas dan golongan minoritas, prinsip-prinsip etika dan moral, dan tingkat serta mutu produktivitas (Zamroni, 2011:47).

Konsep multikulturalisme identik dengan wacana pemikiran, oleh karena itu multikulturalisme adalah sebuah ideologi dan sebuah alat untuk meningkatkan derajat manusia dan kemanusiaannya. Untuk dapat memahami multikulturalisme diperlukan landasan pengetahuan yang berupa bangunan konsepkonsep yang relevan dan mendukung keberadaan serta berfungsinya multikulturalisme dalam kehidupan manusia. Bangunan konsep-konsep ini harus dikomunikasikan di antara para ahli yang mempunyai perhatian ilmiah yang sama tentang multikulturalisme, sehingga terdapat kesamaan pemahaman dan saling 
mendukung dalam memperjuangkan ideologi ini. Berbagai konsep yang relevan dengan multikulturalisme antara lain adalah, demokrasi, keadilan dan hukum, nilai-nilai budaya dan etos, kebersamaan dalam perbedaan yang sederajat, suku bangsa, kesukubangsaan, kebudayaan suku bangsa, keyakinan keagamaan, ungkapan-ungkapan budaya, domain privat dan publik, HAM, hak budaya komunitas, dan konsep-konsep lainnya yang relevan (Achmad, 2001:27).

Selanjutnya Suparlan

mengutip Fay (1996), Jary dan Jary (1991), Watson (2000) dan Reed (ed. 1997) (Suparlan, 2002:47) menyebutkan bahwa multikulturalisme ini akan menjadi acuan utama bagi terwujudnya masyarakat multikultural, karena multikulturalisme sebagai sebuah ideologi akan mengakui dan mengagungkan perbedaan dalam kesederajatan baik secara individual maupun secara kebudayaan. Dalam model multikulturalisme ini, sebuah masyarakat (termasuk masyarakat Indonesia) mempunyai sebuah kebudayaan yang berlaku umum dalam masyarakat tersebut yang coraknya seperti sebuah mosaik. Dengan demikian, multikulturalisme diperlukan dalam bentuk tata kehidupan masyarakat yang damai dan harmonis meskipun terdiri dari beraneka ragam latar belakang kebudayaan.

\begin{abstract}
Mengingat pentingnya pemahaman mengenai konsep multikultural dalam membangun kehidupan berbangsa dan bernegara, terutama bagi negara-negara yang mempunyai aneka ragam budaya seperti di Indonesia, maka pendidikan multikultural ini perlu dikembangkan. Melalui pendidikan komunikasi multikultural diharapkan akan dicapai suatu kehidupan masyarakat yang damai, harmonis, dan menjunjung tinggi nilai-nilai kemanusiaan sebagaimana yang telah diamanatkan dalam undang-undang dasar.
\end{abstract}

\section{Pendidikan multikultural}

yang marak didengungkan sebagai langkah alternatif dalam rangka mengelola masyarakat multikultur di Indonesia, akan tetapi tampaknya masih menjadi wacana belaka. Artinya gagasan ini belum mampu diejawantahkan, baik oleh masyarakat maupun pemerintah, dalam tindakan praksis (Djohar. 2003 dan Sabrina 2008:18).

Oleh karena itu, melalui kajian ini layak jika kita meneguhkan kembali paradigma multikultural tersebut. Peneguhan ini harus lebih ditekankan kepada persoalan kompetensi kebudayaan, sehingga tidak hanya berkutat pada aspek kognitif melainkan beranjak kepada aspek psikomotorik. Peneguhan ini bermaksud menggugah kesadaran bahwa makna multikultural, sebagaimana diungkap oleh 
Goodenough (1976) adalah pengalaman normal manusia. Ia ada dan hadir dalam realitas empirik. Untuk itu, pengelolaan masyarakat multikultural Indonesia tidak bisa dilakukan secara taken for granted atau trial and error. Sebaliknya harus diupayakan secara sistematis, terprogram, integrated, dan berkesinambungan (Hernandez, 1989;18). Di sinilah fungsi strategis pendidikan komunikasi multikultural sebagai sebuah proses di mana seseorang dapat mengembangkan kompetensi dalam beberapa sistem standar untuk mempersepsi, mengevaluasi, meyakini, dan melakukan tindakan.

Beberapa hal yang dibidik dalam pendidikan komunikasi multikultural ini adalah: pertama, pendidikan multikultural menolak pandangan yang menyamakan pendidikan (education) dengan persekolahan (schooling) atau pendidikan multikultural dengan program-program sekolah formal. Pandangan yang lebih luas mengenai pendidikan sebagai transmisi kebudayaan juga bermaksud membebaskan pendidik dari asumsi bahwa tanggung jawab primer dalam mengembangkan kompetensi kebudayaan semata-mata berada di tangan mereka, melainkan tanggung jawab semua pihak (Djohar, 2003:47-48).

Kedua, pendidikan juga menolak pandangan yang menyamakan kebudayaan dengan kelompok etnik. Sebab para pendidik sering mengasosiasikan kebudayaan hanya dengan kelompok-kelompok sosial yang relatif self sufficient. Oleh karena individu-individu memiliki berbagai tingkat kompetensi dalam berbagai dialek atau bahasa, dan berbagai pemahaman mengenai situasi-situasi di mana setiap pemahaman tersebut sesuai, maka individu-individu memiliki berbagai tingkat kompetensi dalam sejumlah kebudayaan. Dalam konteks ini, pendidikan multikultural akan melenyapkan kecenderungan yang memandang individu secara stereotip menurut identitas etnik mereka. Malah akan meningkatkan eksplorasi pemahaman yang lebih besar mengenai kesamaan dan perbedaan di kalangan anak-didik dari berbagai kelompok etnik.

$\begin{array}{lr}\text { Ketiga, } & \text { pendidikan } \\ \text { komunikasi } & \text { multikultural } \\ \text { meningkatkan } & \text { kompetensi dalam }\end{array}$
beberapa kebudayaan. Kebudayaan mana yang akan diadopsi seseorang pada suatu waktu ditentukan oleh situasinya. Meski jelas berkaitan, harus dibedakan secara konseptual antara identitas-identitas yang disandang individu dan identitas sosial primer dalam kelompok etnik tertentu.

$\begin{array}{lr}\text { Keempat, } & \text { kemungkinan } \\ \text { bahwa pendidikan } & \text { komunikasi } \\ \text { multikultural meningkatkan } \\ \text { kesadaran mengenai kompetensi } \\ \text { dalam beberapa kebudayaan akan }\end{array}$


menjauhkan kita dari konsep dwibudaya (bicultural) atau dikotomi antara pribumi dan non-pribumi. Karena dikotomi semacam ini bersifat membatasi kebebasan individu untuk sepenuhnya mengekspresikan diversitas

kebudayaan.

$$
\text { Dalam melaksanakan }
$$

pendidikan komunikasi multikultural ini mesti dikembangkan prinsip solidaritas (Ainul Yaqin, 2005: 24, dan Ma'arif, 2005:18). Yakni kesiapan untuk berjuang dan bergabung dalam perlawanan demi pengakuan perbedaan yang lain dan bukan demi dirinya sendiri. Solidaritas menuntut untuk melupakan upaya-upaya penguatan identitas melainkan berjuang demi dan bersama yang lain. Melalui konsep demikian, kehidupan multikultural yang dilandasi kesadaran akan eksistensi diri tanpa merendahkan yang lain diharapkan dapat terwujud.

Dari berbagai keterangan di atas pendidikan komunikasi multikultural sangat penting untuk diterapkan guna meminimalisasi dan mencegah terjadinya konflik di daerah maupun di pusat. Melalui pendidikan berbasis multikultural, sikap dan mindset (pemikiran) siswa maupun mahasiswa akan lebih terbuka untuk memahami dan menghargai keberagaman budaya nusantara sebagai identitas lokal dan nasional. Pendidikan komunikasi multikultural sangat penting diterapkan guna meminimalisasi dan mencegah terjadinya konflik, contonya seperti konflik masyarakat di Kalimantan Barat, Ambon, Papua, konflik siswa dan mahasiswa dan lainnya.

\section{c. Implementasi Pendidikan Komunikasi Multikultural Sebagai Penguatan Identitas Nasional}

Penulis berpandangan bahwa Indonesia adalah negara yang majemuk, hal ini dapat ditinjau dari sudut pandang; geografis, agama, suku, ras, kebudayaan, adat-istiadat, bahasa, seni, dan lain sebagainya. Dalam kehidupan yang beragam seperti ini menjadi tantangan besar untuk mempersatukan bangsa Indonesia menjadi satu kekuatan yang dapat menjunjung tinggi perbedaan dan keragaman masyarakatnya.

Hal ini dapat dilakukan melalui pendidikan komunikasi multikultural yang ditanamkan kepada siswa dan mahasiswa lewat pembelajaran formal maupun di non formal. Seorang pendidik dalam hal ini guru maupun dosen bertanggung jawab dalam memberikan pendidikan terhadap anak didiknya dan dibantu oleh orang tua dalam melihat perbedaan yang terjadi dalam kehidupan mereka sehari-hari. Jadi, pendidikan komunikasi multikultural bukan hanya sebatas kepada anakanak usia sekolah tetapi juga kepada 
mahasiswa dan masyarakat Indonesia pada umumnya lewat acara atau seminar yang menggalakkan pentingnya toleransi dalam keberagaman menjadikan masyarakat Indonesia dapat menerima bahwa mereka hidup dalam perbedaan dan keragaman.

Upaya ini juga dapat dilakukan oleh media elektronik (TV), mengingat fungsinya sebagai alat informasi kepada masyarakat. Media berfungsi memberikan pendidikan komunikasi multikultural lewat tulisan dan tayangan yang mengajarkan toleransi masyarakat dalam kehidupan berbangsa dan bernegara. Mengingat media massa dapat berdampak pada pengetahuan, nilai-nilai, sikap dan perilaku, sehingga masyarakat dapat mengetahui secara langsung bagaimana hakikat toleransi yaitu kesediaan untuk hidup berdampingan secara damai dan saling menghargai pihak lain. Apa yang disajikan media kepada masyarakat dapat mempengaruhi kehidupan mereka sehari-hari, sehingga fungsi media sangat berperan dalam memberikan pendidikan multikultural untuk mencapai masyarakat yang saling menyatu dalam bingkai negara Indonesia seperti slogan "Bhineka Tunggal Ika" yang bermakna berbeda-beda namun tetap satu. Ini menyatakan bahwa keragaman dan perbedaan yang ada di Indonesia menjadi kekuatan dalam kehidupan berbangsa dan bernegara.
Jadi, pendidikan multikultural memang sebuah konsep yang dibuat dengan tujuan untuk menciptakan persamaan peluang pendidikan bagi semua warga negara yang berbedabeda ras, etnis, kelas sosial dan kelompok budaya. Salah satu tujuan penting dari konsep pendidikan komunikasi multikultural adalah untuk membantu semua siswa agar memperoleh pengetahuan, sikap dan ketrampilan yang diperlukan dalam menjalankan peran-peran seefektif mungkin pada masyarakat demokrasi-pluralistik (Zamroni, (2010a dalam Sabrina, 2008:40-42). Oleh karena itu, diperlukan untuk berinteraksi, negosiasi, dan komunikasi dengan warga dari kelompok beragam agar tercipta sebuah tatanan masyarakat bermoral yang berjalan untuk kebaikan bersama.

Dalam implementasinya, paradigma pendidikan komunikasi multikultural dituntut untuk berpegang pada prinsip-prinsip berikut ini:
1. Pendidikan
komunikasi multikultural harus menawarkan beragam kurikulum yang merepresentasikan pandangan dan perspektif banyak orang.
2. Pendidikan komunikasi multikultural harus didasarkan pada asumsi bahwa tidak ada penafsiran tunggal terhadap kebenaran sejarah.


3. Kurikulum dicapai sesuai dengan penekanan analisis komparatif dengan sudut pandang kebudayaan yang berbeda-beda (beragam).

4. Pendidikan komunikasi multikultural harus mendukung prinsip-prinisip pokok dalam memberantas pandangan klise tentang ras, budaya dan agama tertentu.

Jadi, pendidikan komunikasi multikultural mencerminkan keseimbangan antara pemahaman persamaan dan perbedaan budaya mendorong individu dalam rangka mempertahankan dan memperluas wawasan budaya dan kebudayaan mereka sendiri.

Beberapa aspek yang menjadi kunci dalam melaksanakan pendidikan multikultural dalam struktur sekolah adalah tidak adanya kebijakan yang menghambat toleransi, termasuk tidak adanya penghinaan terhadap ras, etnis dan jenis kelamin. Juga, harus menumbuhkan kepekaan terhadap perbedaan budaya, diantaranya mencakup percakapan, pakaian, musik, dan makanan kesukaan. Selain itu, juga memberikan kebebasan bagi masyarakat dalam merayakan hari-hari besar umat beragama serta memperkokoh sikap siswa, mahasiswa, dan masyarakat umum agar merasa butuh terlibat dalam pengambilan keputusan secara demokratis.

Kenyataan yang tak dapat ditolak bahwa masyarakat dan bangsa Indonesia terdiri dari berbagai keragaman sosial, kelompok etnis, budaya, agama, aspirasi politik dan lain-lainnya, sehingga "masyarakat dan bangsa Indonesia secara sederhana dapat disebut sebagai masyarakat dengan keanekaragaman budaya. Pada pihak lain, realitas keanekaragaman tersebut berhadapan dengan kebutuhan mendesak untuk merekonstruksi kembali "kebudayaan nasional Indonesia" atau "budaya bangsa" yang dapat menjadi "integrating force" yang dapat mengikat seluruh keragaman etnis, suku bangsa dan budaya tersebut". Kesadaran tentang keanekaragaman budaya sudah muncul sejak negara Republik Indonesia terbentuk dan digunakan oleh pendiri bangsa Indonesia untuk" mendesain kebudayaan bangsa Indonesia.

Perbedaan budaya, agama, aspirasi politik, kepentingan, visi dan misi, keyakinan dan tradisi merupakan sebuah konduksi dalam hubungan interpersonal yang kadang-kadang juga menjadi perbedaan perilaku dalam memahami sesuatu. Bangsa Indonesia merupakan masyarakat majemuk karena terdiri dari berbagai suku, bahasa dan agama, terdapat sekitar 
300 dialek bahasa dan ratusan etnik yang tersebar di nusantara ini (Achmad, 2001:7-8). Menurut Fuad Hasan, budaya nusantara yang plural merupakan kenyataan hidup (living reality) yang tidak dapat dihindari. Sebagai hasil cipta, rasa dan karsa masyarakat Indonesia keragaman suku telah melahirkan keragaman budaya, yang terikat dalam slogan bhineka tunggal ika. Kebhinekaan ini harus dipersandingkan bukan dipertentangkan. Keberagaman ini merupakan manifestasi gagasan dan nilai sehingga saling menguatkan dan dimanfaatkan untuk meningkatkan wawasan dalam saling mengapresiasikan (Zakaria, 2002:24).

\begin{tabular}{llr}
\multicolumn{2}{c}{ Kebhinekaan } & budaya \\
Indonesia & menjadi & bahan \\
perbandingan & untuk menemukan
\end{tabular}
persamaan pandangan hidup yang berkaitan dengan nilai kebajikan dan kebijaksanaan (virtue and wisdom). Dengan demikian, keanekaragaman tersebut merupakan satu kenyataan yang harus kita syukuri sebagai kekayaan bangsa, meskipun juga dapat mengandung kerawanankerawanan yang dapat memunculkan konflik kepentingan antar kelompok yang berbeda.

Oleh karena itu, tentu saja kita boleh berbangga, menjadi bangsa Indonesia yang dikaruniai dengan keragaman (kemajemukan/pluralisme) mulai dari agama, etnik, bahasa, budaya dan sebagainya. Fenomena kemajemukan di negara kita tumbuh dari aneka peristiwa sejarah, kolonisasi, migrasi, formasi bangsa dan akhir-akhir ini ditengarai dengan adanya komunikasi global. Dalam jangka waktu yang cukup lama, kemajemukan ini telah menyatukan kita semua menjadi satu kekuatan besar di Asia Tenggara dan selalu diperhitungkan dalam kebijakan politik luar negeri negara-negara besar. Hanya saja, kekayaan dan kekuatan dalam kemajemukan ini, seringkali mendapatkan cobaan yang membawa pada kehidupan penuh curiga, saling menyalahkan dan berujung dengan konflik yang memakan korban manusia.

Sebagai negara dengan jumlah penduduk nomor empat setelah Cina, India dan Amerika Serikat dengan jumlah etnis tidak kurang dari 1.072 telah menggambarkan kondisi etnik yang beragam dengan segala kompleksitasnya (Adian, 2002:2829). Kemajemukan Indonesia ditandai oleh adanya suku-suku bangsa, masing-masing mempunyai cara-cara hidup atau kebudayaan yang berlaku, sehingga mencerminkan adanya pembedaan dan pemisahan antara suku bangsa satu dengan yang lainnya. Perbedaan yang ada di antara kebudayaan suku bangsa di Indonesia pada hakikatnya adalah perbedaan yang disebabkan oleh perbedaan sejarah dan adaptasi terhadap lingkungannya. Kemajemukan etnik sering dianggap 
sebagai persoalan terutama saat meletus konflik kepentingan antara negara dan komunitas berbasis etnik. Berbagai bentuk konflik antar etnik di Indonesia, seperti di Sambas, Ambon, Papua dan Aceh menjadi contoh penguatan basis etnik di antara anggota komunitas yang ada di tingkat lokal (Mering, 2002:51). Dengan demikian, harus diakui bahwa Indonesia merupakan sebuah konsep negara bangsa yang terdiri atas keragaman etnik dan masingmasing etnik mengembangkan sifat komunalisme secara otonom.

$$
\text { Pandangan selanjutnya }
$$

integrasi nasional Indonesia yang tercipta menurut pandangan Christine Drake bersifat multidimensi, kompleks dan dinamis. Indonesia merupakan negara bangsa yang menurut Walker Connor (1971:1) dalam Leo Suryadinata 1999:2) dinyatakan sebagai sebuah bangsa yang terdiri atas berbagai kelompok etnik. Oleh karenanya Drake dalam bukunya yang berjudul National Integration: Indonesia Patterns Policies (Leo Suryadinata 1999:2-4) memandang pilar integrasi nasional berdasarkan hal berikut:

\section{National integration}

incorporates a number of different.

First, common, integrative historical experiences obvionsly act as a cohesive force. Second, shared sosialcultural attributes can help give a nation state its identity, distingnish it from surrounding states and enable its citizens to fell a tense of unity. Third, interaction among the diverse peoples within a nation state promotes integration, especially among those who share various socio cultural attributes. Fourth, regional economic in independence iand sane measure of regional valance economics ....Kutipan tersebut mempertegas, bahwa integrasi nasional, khususnya Indonesia sangat tergantung pada empat hal fundamental tersebut yang terdiri dari atas pengalaman sejarah atau masa lalu, sosio-kultural, interaksi, dan aktivitas ekonomi yang dinamis.

Secara geografis kemajemukan Indonesia juga ditandai dengan karakter penduduk yang tinggal di pedesaan, pegunungan, lembah, dataran dan pantai yang mampu hidup berdampingan. Kemajemukan juga ditemukan pada bahasa, nilai, norma, tradisi dan way o life masing-masing etnik pendukungnya. Sejarah telah menorehkan realitas keberhasilan hidup dalam kemajemukan melalui wujud kemerdekaan sebagai kerja keras bersama tanpa dibatasi oleh identitas etnis, agama, budaya dan sebagainya. Dalam analisis Hawasi (2005) dinyatakan terdapat tiga istilah yang menggambarkan kondisi masyarakat dengan berbagai macam ras, agama, bahasa dan budaya, yaitu pluralitas (plurality), keragaman (diversity), dan multikultutal. Ketiga 
istilah tersebut mengambarkan konsep dasar yang sama, yaitu mengacu pada ketidaktunggalan.

Pluralisme atau kemajemukan mengandaikan adanya hal-hal yang lebih dari satu keragaman, menunjukkan keberadaan yang lebih dari satu, itu berbeda-beda, heterogen dan memungkinkan untuk tetap lestari. Dalam pandangan Ahmad Fedyani ( Fedyani, 2002:36) masyarakat plural, memiliki ciri-ciri sebagai berikut: 1). Masyarakat terdiri atas kelompok dengan latar budaya dan sub budaya berbeda, 2). Masyarakat memiliki struktur sosial yang terbagi dalam lembaga-lembaga yang versita non komplementer, 3). Kurang memiliki kemauan untuk menemukan konsensus, 4). Konflik dan kekerasan berlangsung karena adanya kekerasan serta saling ketergantungan ekonomi.

Multikultural, merupakan konsep baru dengan penekanan pada segala perbedaan itu adalah sama di ruang publik. Dengan kata lain adanya komunitas yang berbeda tidak cukup sebab yang terpenting adalah komunitas itu diperlakukan sama oleh negara. Dalam multikultural terdapat interaksi akti antar anggota masyarakat dan budaya yang plural dalam kehidupan seharihari. Terdapat nuansa kesetaraan dan keadilan dalam unsur-unsur sosial tersebut. Prinsip multikulturalisme mencakup pengakuan pada keanekaragaman, perbedaan, kesederajatan, persamaan, penghormatan pada demokrasi dan solidaritas.

Watson, memaknai multikulturalisme lebih luas lagi, yaitu masyarakat yang di dalamnya berkembang banyak kebudayaan. Sementara itu Kymlicka menjelaskan multikulturalisme sebagai tuntutan pengakuan atas identitas kelompok yang berkembang dan penerimaan perbedaan kebudayaan yang berkembang. Hal ini menjadi penting bagi bangsa Indonesia karena akta keragaman ini membawa konsekuensi logis yang mungkin timbul dan kepentingan integrasi nasional.

Kalau dalam retorika lama terdengar semboyan berbeda-beda tetapi satu, maka dengan adanya tuntutan akan kemajemukan, terjadi pembalikan besar dalam semboyan tersebut: satu tetapi berbeda-beda. Kesadaran tentang pluralisme budaya memang sudah ada dalam kesadaran kolektif di nusantara ini sejak lama. Terdapat banyak kelompok budaya, kelompok etnik dan suku serta kelompok agama. Namun demikian dalam pandangan Ignas Kleden dinyatakan bahwa keaneka-ragaman budaya itu dipandang tak berbeda dari keanekaragaman hayati dengan dua asumsi utama. Pertama, perbedaan budaya dianggap terdapat antara satu kelompok budaya dan kelompok budaya lain. Kedua, perbedaan-perbedaan itu sudah ada begitu saja secara "alamiah" dan sepatutnya diterima dan dihormati. 
Masalah kemajemukan budaya, pluralisme etnis, bahasa, ras, dan agama sesungguhnya merupakan realitas yang sudah lama ada dalam masyarakat Indonesia. Perlakuan terhadap masalah kemajemukan dilakukan dengan cara dialog, toleransi, dan penegakkan HAM. Mengapa? Karena, perbedaan ini sering memicu konflik, yang bila tidak diselesaikan dapat menimbulkan kerusuhan dengan pelanggaran HAM yang lebih luas. Dalam pandangan Charles Taylor, konflik biasanya berangkat dari reaksi kelompok minoritas untuk menuntut hak dalam kesertaannya untuk menentukan jalannya kebijakan publik dan untuk menetapkan diri sebagai manusia. Multikulturalusme sebagai paradigma baru layak untuk disebarluaskan untuk dapat merajut kembali hubungan antar manusia yang terkoyak karena konflik. Melalui multikulturalisme diharapkan akan muncul kesadaran bersama terhadap kenyataan kemajemukan (pluralitas) yang banyak teraleniasi oleh kehidupan modern, baik pada tataran kemajemukan etnik, agama, tradisi, bahasa, budaya hingga orientasi politik.

Jadi penulis menegaskan bahwa Ragam Indonesia sebagai salah satu tayangan televisi di Indonesia telah menyuguhkan tayangan yang mampu dijadikan modal dalam rangka mengembangkan inovasi pendidikan komunikasi multikultural, mengingat tayangan-tayangan dalam Ragam Indonesia meliputi kenyataan aspek kehidupan; ekonomi, religi, tradisi, serta identitas lokal yang dapat dikemas menjadi identitas nasional sebagai materi pembelajaran siswa, mahasiswa, dam masyarakat umum.

\section{Penutup}

\section{a. Kesimpulan}

Berdasarkan kajian di atas, dapat disimpulkan bahwa:

1. Pendidikan komunikasi multikultural dapat dimaknai sebagai upaya melakukan pembelajaran serta peningkatan demokratisasi peserta didik dalam menghadapi perbedaan budaya. Oleh karena itu, pendidikan komunikasi multikultural adalah merupakan suatu wacana lintas batas dari keragaman budaya nusantara. Artinya perbedaan perlu disadari bukan sebagai menjadi penyebab konflik.

2. RAGAM INDONESIA merupakan salah satu materi tanyangan media televisi khususnya TRANS7 disajikan setiap hari Senin sampai Jumat pukul 06.00 sampai dengan 06.30 (durasi 30 menit), namun saat ini mulai tayang pada pukul 05.40. Waktu atau durasi tersebut memang hanya sebentar, namun di balik tayangan ini memiliki 
makna serta pesan edukasi bagi anak bangsa terkait pembentukan karakter terhadap penguatan nilainilai multikultural di Indonesia sebagai modal membangun penguatan identitas nasional.

3. Materi tayangan ini meliputi keragaman sosial ekonomi, nilainilai adat-istiadat, seni, religi, bahasa, wisata yang meliputi wisata religi, niaga, alam, dan berbagai jenis wisata kuliner nusantara. Kemudian dalam identitas budaya lokal lainnya terkait ekonomi kreatif masyarakat kota dan desa. Oleh karena itu materi tayangan Ragam Indonesia sangat informatif dalam kajian ini, sehingga wawasan budaya nusantara dapat menjadi modal dan model pembelajaran terkini bagi generasi muda.

4. Alasan dipilihnya Stasiun TRANS7 karena stasiun ini memiliki komitmen kepada publik dalam menayangkan ragam identitas sosial-budaya Indonesia. Untuk itu melalui penelitian ini, penulis berkesimpulan bahwa materi tayangan RAGAM INDONESIA dapat menjadi inspirasi dan inovasi pembelajaran baik siswa, mahasiswa, maupun masyarakat umum dalam memahami keanekaraman budaya nusantara.

\section{b. Saran/Rekomendasi}

1. Diharapkan bagi peneliti selanjutnya dan yang serupa agar lebih mendalam dengan menggunakan pendekatan lain, sehingga hasil penelitian mampu memberikan wawasan akademik yang lebih mendalam dan informatif.

2. Bagi praktisi lembaga televisi penyiaran publik, khususnya TRANS7 diharapkan tetap konsisten dalam menayangkan materi siarannya khususnya Ragam Indonesia, sehingga dapat dijadikan inspirasi dalam membangun nilai-nilai identitas nasional sebagai kekuatan budaya bangsa.

3. Bagi para praktisi pendidikan baik pada tingkat sekolah maupun perguruan tinggi, diharapkan menjadikan tayangan Ragam Indonesia sebagai salah satu pertimbangan untuk dijadikan modal serta model pengembangan kurikulum dalam proses pembelajaran.

4. Bagi para pendidik, peserta didik, serta masyarakat diharapkan mampu menjadikan materi tayangan televisi sebagai salah satu pertimbangan tontonan sebagai tuntunan, serta tatanan di masyarakat. 


\section{DAFTAR PUSTAKA}

Abdullah, Taufik (Ed). 1983. Agama dan Perubahan Sosial. Jakarta: Rajawali

Achmad, Nur. 2001. Pluralitas Agama, Kerukunan Dalam Keragaman. Jakarta: Kompas-Gramedia

Ainul Yaqin, M. 2005. Pendidikan Multikultural Cross-Cultural Understanding untuk Demokrasi dan Keadilan. Yogyakarta: Pilar Media.

Banks, James A. 2002. An introduction to Multicultural Education, Boston London: Allyn and Bacon Press

2007. Educating citizens in multicultural society. Second edition. New York: Teachers College Columbia University.

Colleman, James S. 2008. Dasar-Dasar Teori Sosial, (Terj. Imam Muttaqien, Derta Sri Widowtie dan Siwi Purwandari). Bandung: Nusa Media Crapps

Creswell, John W. 2010. Research Design Pendekatan Kualitatif, Kuantitatif, dan Mixed. Yogjakarta: Pustaka Pelajar

Dahrendorf, Ralf. 1986. Konflik dan Konflik Dalam Masyarakat Industri, Sebuah Analisa Konfik. (Jakarta: Rajawali, Departemen Agama RI. Al-Qur'an dan Terjemahannya. Jakarta: Intermassa

Digdoyo, Eko. 2015. Ilmu Sosial dan Budaya Dasar. Bogor: PT Galia Indonesia

Fedyani, S. Ahmad. 2002. Pendidikan Multikultural: Kemungkinan dan Batas Batas. Jakarta: Yayasan Sains Estetika dan Teknologi.

Garal, Adian Donny 2002. Multikulturalisme, Politik dan Solidaritas. Jakarta: Yayasan Sains Estetika dan Teknologi.

Giddens, Anthony. 1987. Perdebatan Klasik dan Kontemporer Mngenai Kelompok, Kekuasaan dan Konflik. Jakarta: Rajawali

Hamidi. 2004. Metode Penelitian Kualitatif - Aplikasi Praktis Pembuatan Proposal dan Laporan Penelitian. Malang: UMM Pres

Mahfud, Choirul. 2008. Pendidikan Multikultural. Yogyakarta: Pustaka Pelajar

Nur, Achmad, (ed.). 2001. Pluralitas Agama Kerukunan Dalam Keragaman. Jakarta: PT. Gramedia

Hasyim, H. A Dardi, Yudi Hartono. 2004. Pendidikan Multikultural di Sekolah. Surakarta: UPT penerbitan dan percetakan UNS. 
Koentjaraningrat. 1974. Kebudayaan, Mentalitas dan Pembangunan. Jakarta: PT. Gramedia . 1997. Metode-Metode Penelitian Masyarakat. Jakarta: PT. Gramedia Pustaka Utama

Ngo, Mering. 2002. Kemajemukan dan Keanekaragaman: Menggagas Transformasi Konflik Sosial dan Politik. Jakarta: Yayasan Sains Estetika dan Teknologi.

Nuraeni, Heny Gustini. 2013. Studi Budaya di Indonesia. Bandung: Pustaka Setia

Ranjabar, Jacobus. 2006. Sistem Sosial Budaya Indonesia. Bogor: Ghalia Indonesia

Robert W. 1993. Dialog Psikologi dan Agama (Terj. A.M. Hardjana). Yogyakarta: Kanisius

Setiadi, Eli M. 2010. Ilmu Sosial dan Budaya Dasar. Jakarta: Prenada

Salim, Agus. 2002. Perubahan Sosial; Sketsa Teori dan Refleksi Metodologi Kasus Indonesia. Jogyakarta: Tiara Wacana

Tilaar, H. A. R. 2002. Pendidikan, Kebudayaan dan Masyarakat Madani Indonesia. Jakarta: Remaja Rosdakarya.

Wridgh, Charles R. 1985. Sosiologi Komunikasi Massa (Terj. Lilawati Trimo dan Jalaluddin Rahmat). Bandung: Remadja Karya

Yaqin, M. Ainul. 2005. Pendidikan Multikultural Cross-Cultural Understanding untuk Demokrasi dan Keadilan. Yogyakarta: Pilar Media.

Zamroni. 2011. Pendidikan Demokrasi pada Masyarakat Multikultural. Yogyakarta: Gavin Kalam Utama.

Zakaria, R. Yando. 2002. Soal Kemajemukan dalam Ketunggalan Negara. Pengantar Garin Nugroho. Jakarta: Yayasan Sains Estetika dan Teknologi.

Internet:

Asy'arie, Musa. 2004. Pendidikan Multikultural dan Konflik Bangsa, http://www.kompas.com/kompas-cetak/0409/03/opini/1246546

Sabrina. (2008). Pentingnya Pendidikan Multikultural. http://s4brina.wordpress.com. Diakses tanggal 25 Oktober 2011

Sartini, 2004. Menggali Kearifan Lokal Nusantara Sebagai Kajian Filsafati. Jurnal Filsafat. 37 (2): 111-120. wordpress.com/2009 (Diakses 10 April 2009) 
67 Eko Digdoyo: pengembangan invovasi pendidikan komunikas multikultural ...

Suparlan, Parsudi. 2002. Menuju Masyarakat Indonesia yang Multikultural. http://www.scripp.ohiou.edu/news/cmdd/artikel-ps.htm. Diakses tanggal 25 Oktober 2011.

Kompas, 29 Maret 2014

Kompas, 19 April 2014 